\title{
Economic and biological evaluation of Chinese cabbage [Brassica rapa L. var. pekinensis (Lour.) Kitam.] hybrids grown in the Right-Bank Forest Steppe of Ukraine
}

\author{
Z. I. Kovtuniuk ${ }^{1 *}$, V. I. Voitovska ${ }^{2}$, L. I. Storozhyk ${ }^{2}$ \\ ${ }^{1}$ Uman National University of Horticulture, 1 Instytutska St., Uman, Cherkasy Region, 20305, Ukraine, e-mail: kovpetfom@ukr.net \\ ${ }^{2}$ Institute of Bioenergy Crops and Sugar Beet, NAAS of Ukraine, 25 Klinichna St., Kyiv, 03110, Ukraine
}

\begin{abstract}
Purpose. To study the economic and biological characteristics and to reveal the genetic potential of various hybrids of Chinese cabbage depending on the climatic zone of cultivation. Methods. In the experiment, hybrids of Chinese

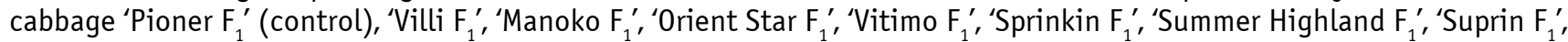
and 'Richi $F_{1}$ ' were evaluated. The experiment was laid out in a randomized block design with four replications with a single plot area of $21 \mathrm{~m}^{2}$. The container seedlings ( 40 days old) were planted in the middle of April according to the scheme $70 \mathrm{~cm}$ by $25 \mathrm{~cm}$. Results. Having been planted at the same time, seed germination over the studied hybrids was not simultaneous. The first sprouted seeds ( 4 days after seeding) belonged to hybrids 'Villi $F_{1}^{\prime}$, 'Manoko $F_{1}^{\prime}$, 'Orient Star $F_{1}^{\prime}$ ', and 'Summer Highland $F_{1}$ '. Seeds of the other hybrids started active germination on the $5-6$ days after seeding. The highest yield of the cabbage heads was obtained from hybrids 'Villi $F_{1}^{\prime}$ (31.7 t/ha) and 'Sprinkin $F_{1}^{\prime}$ (28.7 t/ha), which was 10.0 and $7.0 \mathrm{t}$ /ha more than in the control variant. The yield of 'Summer Highland $\mathrm{F}_{1}^{\prime}$ was $24.9 \mathrm{t} / \mathrm{ha}$ and 'Suprin $\mathrm{F}_{1}$ ' $24.6 \mathrm{t} / \mathrm{ha}$. Under the conditions of unstable soil moisture, hybrids 'Villi $\mathrm{F}_{1}$ 'and 'Sprinkin $\mathrm{F}_{1}{ }^{\prime}$ appeared the most productive and ensured yield increase of $10.0 \mathrm{t} / \mathrm{ha}$ and $7.0 \mathrm{t} / \mathrm{ha}$, respectively, compared to the control; and crop commercial quality was high. The highest percentage of dry matter (DM) content was in 'Summer Highland $F_{1}^{\prime}(6.2 \%)$ followed by 'Sprinkin $F_{1}$ ' $(5.9 \%)$, which was $1.1 \%$ and $0.8 \%$ more than in the control. There was no significant difference between the values of the total sugars content over the variants. They ranged between 1.7 and 2.1\%, which was similar to the control values. The content of nitrates in the cabbage heads of the studied Chinese cabbage hybrids was within the tolerance limit and amounted to $600 \mathrm{mg} / \mathrm{kg}$ (raw mass). Conclusions. Phenological observations of plant development and their biometric indices, depending on the varietal characteristics, indicate that under the conditions of unstable soil moisture, hybrids 'Villi $F_{1}^{\prime}$ and 'Sprinkin $F_{1}^{\prime}$ were more yielding and ensured yield increase of $10.0 \mathrm{t} /$ ha and $7.0 \mathrm{t} /$ ha, respectively, compared to the control. The crop commercial quality was high. The long growing season of 'Richi $F_{1}^{\prime}$ (93 days) did not affect the crop quality and yield and demonstrated the lowest productivity compared to the control and the other experiment variants.
\end{abstract}

Keywords: cabbage head; biometric indicators; phenological observations; nitrate content, yield.

\section{Introduction}

Nowadays olericulture is aimed at providing the population with fresh vegetables. The need for them is far from being fully satisfied, there is a poor assortment of vegetables both in the public and in the individual sector, the seasonality of fresh produce, low productivity and

\section{Zoia Kovtuniuk}

https://orcid.org/0000-0001-6581-2315

Viktoriia Voitovska

https://orcid.org/0000-0001-5538-461X

Larysa Stotrozhyk

https://orsid.org/0000-0003-1587-1477 product quality and a low percentage of its sale [1]. Chinese cabbage, as an early-ripe crop, is becoming more and more popular with consumers every year and, accordingly, its cultivation areas are increasing. The growing demand for chinese cabbage is due to the growing culture of its consumption by the population and its unique chemical composition. Chinese cabbage has a low energy value $-125 \mathrm{~kJ} / 100 \mathrm{~g}$ of product, and heads rich in sugar $-1.5-3.8 \%$, starch up to $0.4 \%$, fiber - up to $0.7-1.2 \%$, calcium $0.95 \%$, phosphorus $-1.16 \%$, potassium $-0.36 \%$, and sodium $-0.16 \%$ [2]. In a short period, the plant forms nutritionally valuable greens. $100 \mathrm{~g}$ of fresh produce contains up to $1 \mathrm{~g}$ 
of protein, $0.3 \mathrm{~g}$ of fat, $250 \mathrm{mg}$ of potassium, 0.9-1.3 $\mathrm{mg}$ of iron. The refined taste and aroma of its fresh leaves stimulates appetite, increases the ability to assimilate [3, 4].

Fifteen years ago in Ukraine Chinese cabbage leafy varieties called lettuce, prevailed; now head forming varieties of foreign breeding are mainly grown, which brought the culture of its consumption to the level of white cabbage with high productivity and product quality [5]. When choosing a variety or hybrid, one should take into account its resistance to bolting, a suitable growing period, and head weight. A variety as a biological system determines the degree of use of environmental and technogenic resources. Therefore, breeding under market conditions should respond specifically to the needs of the time and be aimed at drought tolerance, adaptability, early maturity, quality and a high low-threshold for the productivity of vegetable raw materials [6, 7].

Chinese cabbage is a promising early vegetable crop. In Ukraine, there is a small assortment of domestic varieties and hybrids of Chinese cabbage with a high potential for productivity of various ripeness groups, indicators of the quality of commodity and seed production that are resistant to diseases [5, 8]. Therefore, an important element of agricultural technology for the cultivation of chinese cabbage is the selection of modern varieties and hybrids of the intensive type, high-yielding, resistant to bolting. Their diversity is much less than that of white cabbage and they differ mainly in the shape and weight of the head. Varieties and hybrids with elongated cylindrical heads are more popular.

Chinese cabbage is quite demanding on growing conditions, especially in greenhouses [7]. Market for its products is growing every year and is associated with a rich chemical composition, medicinal properties and longterm storage ability $[1,8]$.

One of the requirements for choosing is boltresistant varieties. Varieties and hybrids are divided into two groups according to the timing of cultivation, in particular, are recommended for spring and autumn cultivation. The size of the head of cabbage depends on the biological characteristics of the variety or hybrid and the density of sowing or seedling planting schemes. The mass of the head can vary from 1 to $5 \mathrm{~kg}$ or more, depending on the growing technology. Heads weighing $0.8-1.5 \mathrm{~kg}$ are more popular among consumers $[1,9,10]$. A characteristic feature of most hybrids is the ability of the leaves not to lose their dark green color even during prolonged storage.
In Ukraine, there is currently a tendency for cultivation of hybrids of domestic and foreign breeding, which is associated with the growing requirements of plant resistance to disease, yield and quality of production [2].

The purpose of the research is to study the economic and biological features and uncover the genetic potential of various hybrids of Chinese cabbage, depending on the climatic zone of cultivation.

\section{Materials and methods}

The studies were carried out during 20172019 at the experimental field of the Department of Vegetable Growing of the Uman NUH on black soil podzolic heavy-loam, which was marked by a deep occurrence of carbonates $(115-120 \mathrm{~cm})$ and low content in the arable layer of humus (1.92-2.1\%). According to the problem laboratory of the Uman NUH, the reaction of the soil solution was slightly acidic $(\mathrm{pH}$ 6.25 ), hydrolytic acidity of $2.46 \mathrm{mg}$-eq $/ 100 \mathrm{~g}$ of soil, the content of mobile forms of phosphorus $280 \mathrm{mg} / \mathrm{kg}$ and potassium $278 \mathrm{mg} / \mathrm{kg}$ (according to Chirikov), nitrogen alkaline-hydrolyzed compounds (according to Kornfield) $105.7 \mathrm{mg} / \mathrm{kg}$.

In 2017 the weather conditions were slightly different from perennial values. The spring was long and moderately warm with insufficient rainfall compared to annual average. Average air temperatures in March were $5.5{ }^{\circ} \mathrm{C}$ above the climate normals. Summer of 2017 was warm (average air temperature for the season was $20.9{ }^{\circ} \mathrm{C}$, which is $2.6^{\circ} \mathrm{C}$ above the climate normals), precipitation was $130.1 \mathrm{~mm}$, that is $\mathbf{1 0 2 . 9} \mathrm{mm}$ below the climate normals. The average air temperature in June, July and August was $20.0 ; 20.6$ and $22.1{ }^{\circ} \mathrm{C}$, what was 2.4; 1.6 and $3.9^{\circ} \mathrm{C}$ above normal for the RightBank Forest Steppe. A feature of that summer was the average monthly August temperature, what was higher than July one. In 2018, the amount of precipitation was $680.6 \mathrm{~mm}$, that is, $47.6 \mathrm{~mm}$ more than the climate normals, and the average air temperature by $2.3^{\circ} \mathrm{C}$ exceeded the traditional long-term average and was $9.7{ }^{\circ} \mathrm{C}$. The summer season was characterized by downpours. Thus, in June their number was only $41 \mathrm{~mm}$, which was less by $46 \mathrm{~mm}$ of the climate normals, and in July and August they were by 27.8 and $29.1 \mathrm{~mm}$ less than the average values. In 2019 weather conditions were characterized by uneven rainfall and extremely high temperatures, especially in July, an abnormally hot last decade and extremely hot August with an excess of $37{ }^{\circ} \mathrm{C}$. In general, the weather conditions during the years of re- 
search were typical of the specified area of cultivation.

The object of the study was hybrids of Chinese cabbage of foreign breeding - 'Pioner $F_{1}$ ' (control), 'Vili $\mathrm{F}_{1}$ ', 'Manoko $\mathrm{F}_{1}$ ', 'Orient Star $\mathrm{F}_{1}^{1}$ ', 'Vitimo $\mathrm{F}_{1}$ ', 'Sprinkin $\mathrm{F}_{1}$ ', 'Summer Highland $\mathrm{F}_{1}^{1}$ ', 'Suprin $\mathrm{F}_{1}$ ', 'Richi $\mathrm{F}_{1}$ ', listed in the Register of plant varieties of Ukraine. All hybrids are suitable for cultivation in the Forest-Steppe zone. The average mass of the head is from 1.5 to $2.5 \mathrm{~kg}$, they are characterized by high resistance to disease, bolting and high uniformity. The growing season lasts $60-85$ days.

The container seedlings (40 days old) were planted in the middle of April according to the scheme $70 \mathrm{~cm}$ by $25 \mathrm{~cm}$, i. e. 57.1 thousand plant/ha. The area of the accounting site was $21 \mathrm{~m}^{2}$. The experiment was laid out in a randomized block design with four replications. During the growing season of plants, their phenology was monitored, measurements were made, and analyzes were performed using conventional methods [10]. The content of dry soluble and insoluble substances, ascorbic acid, and nitrates was determined in finished products in laboratory conditions [11]. Plants were cared for in accordance with the requirements of this culture and research questions. They were wa- tered as needed, hilled up, protected from pests and diseases; the soil in the aisles was loosened, weeds were removed. Statistical processing of the results was performed using computer software Excel and Statistica 6.0 [12].

\section{Results and discussion}

Monitoring the rate of passage of the main phenological phases of Chinese cabbage showed that, having been planted within the same time frame seed germination was not simultaneous. The first sprouted seeds (4 days after seeding) belonged to hybrids 'Vili $\mathrm{F}_{1}$ ', 'Manoko $\mathrm{F}_{1}$ ', 'Orient Star $\mathrm{F}_{1}$ ' and 'Summer Highland $\mathrm{F}_{1}$ ', Seeds of the other hybrids started active germination on the 5-6 days after seeding. Even sprouts were in 'Vili F1' and 'Summer Highland $\mathrm{F}_{1}$ ' (95\% germination). The beginning of head formation was observed in the second decade of May in all variants. The duration of the growing season over the course of research was influenced by the sum of effective air temperatures. According to this indicator, most of the hybrids were at the control level 61-62 days from seedlings, unlike 'Richi $\mathrm{F}_{1}$ ' hybrid, where the phase of head formation occurred on average 4 days later during the years of studies (Table 1).

Table 1

The duration of the interphase periods in hybrids of Chinese cabbage, days

\begin{tabular}{|c|c|c|c|}
\hline Hybrids & Mass sprouts & Sprouts - the beginning of head formation & Sprouts - technical maturity \\
\hline ‘Pioner $\mathrm{F}_{1}^{\prime}$ - control & 5 & 62 & 90 \\
\hline 'Vili $\mathrm{F}_{1}^{\prime}{ }^{\prime}$ & 4 & 62 & 89 \\
\hline 'Manoko $\mathrm{F}_{1}^{\prime}$ & 4 & 62 & 89 \\
\hline ‘Orient Star $\mathrm{F}_{1}^{\prime}$ & 4 & 64 & 87 \\
\hline 'Vitimo $\mathrm{F}_{1}^{\prime}$ & 6 & 64 & 92 \\
\hline 'Summer Highland $\mathrm{F}_{1}^{\prime}$ & 4 & 62 & 89 \\
\hline 'Sprinkin $\mathrm{F}_{1}$ ' & 5 & 62 & 87 \\
\hline 'Suprin $\mathrm{F}_{1}^{\prime}$ & 6 & 61 & 85 \\
\hline${ }^{\prime}$ Richi $F_{1}^{\prime}{ }^{1}$ & 5 & 66 & 93 \\
\hline
\end{tabular}

'Sprinkin $\mathrm{F}_{1}$ ' hybrid (85 days after sprouting) entered the technical maturity stage early, 5 days faster than the control. The long growing season was observed in the 'Richi $F_{1}$, hybrid - 93 days. The duration of the growing season in other variants was at the level of control.

In the phase of the beginning of head formation, plants of 'Sprinkin $\mathrm{F}_{1}$ ' hybrid $(16.5 \mathrm{~cm})$ were tall at the control level. This indicator was at the same level in hybrids 'Vili $\mathrm{F}_{1}$ ' and 'Summer Highland $\mathrm{F}_{1}$ ', respectively 15.7 and $15.5 \mathrm{~cm}$. The lowest plant height was observed in hybrids 'Richi $\mathrm{F}_{1}$ ' $(14.5 \mathrm{~cm})$, which is explained by the varietal features of plants. In the technical ripeness phase, the plants differed between variants on this indicator. Thus, the plant height of 'Pi- oner $\mathrm{F}_{1}$ ' hybrids (control), 'Vili $\mathrm{F}_{1}$ ' and 'Summer Highland $\mathrm{F}_{1}$ ' was almost the same, with a slight difference. Hybrid 'Sprinkin $\mathrm{F}_{1}$ ' $(31.5 \mathrm{~cm})$ had the highest growth force, the smallest was in 'Richi $\mathrm{F}_{1}$ ' hybrid $(24.0 \mathrm{~cm})$, which is $3.1 \mathrm{~cm}$ less than in the control. During the growing season the number of leaves in the rosette was determined in dynamics. In the phase of the beginning of head formation, more leaves were formed by the plants of hybrids 'Vili $\mathrm{F}_{1}$ ' and 'Summer Highland $F_{1}$ ', respectively 13.5 and 13.0 pcs./plant, 2.6-3.1 more than in the control. The lowest number of leaves was observed in hybrid 'Richi $\mathrm{F}_{1}$ ' $9.1 \mathrm{pcs}$./plant, less than in the control variant.

In the phase of technical maturity, the biggest leafage of plants was observed in hybrids 'Vili $\mathrm{F}_{1}$ ' and 'Sprinkin $\mathrm{F}_{1}$ '; on average over the 
years of research, the number of leaves was 21.7 and $21.4 \mathrm{pcs} . /$ plant, which was 1.6 and $1.3 \mathrm{pcs}$. more than in the control. Plants of hybrid 'Summer Highland $F_{1}$ ' in this phase formed the smallest number of leaves 18.3 pcs., what was 1.8 pcs. less than in the control.

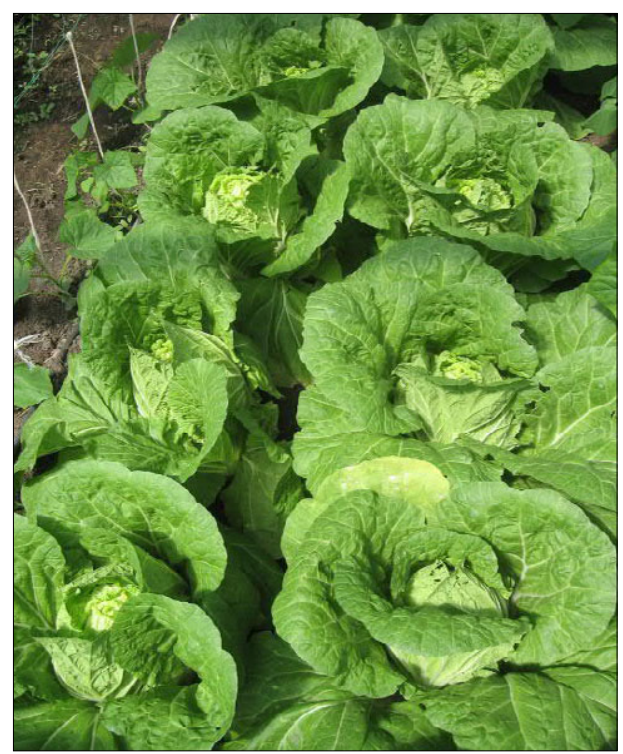

Fig. 1. Plants of the hybrid 'Summer Highland $F_{1}$ '

Qualitative indicators, on average, did not vary significantly over the years. In the structure of the commercial crop of Chinese cabbage, the height, weight and diameter of the heads were determined (Table 2). Analysis of the results showed that on average the highest height $(14.2$ and $15.6 \mathrm{~cm})$ and the head weight (2.1 and $1.7 \mathrm{~kg}$ ) were in hybrids 'Vili $\mathrm{F}_{1}$ ' and 'Summer Highland $\mathrm{F}_{1}$ ', respectively by 2.3 and $3.7 \mathrm{~cm}$ and 0.7 and $0.4 \mathrm{~kg}$ more than in the control, what had a positive effect on the value of gross product. 'Sprinkin $\mathrm{F}_{1}$ ' hybrid formed narrowed heads with a diameter of $11.8 \mathrm{~cm}$, a height of $21.9 \mathrm{~cm}$ and a mass of $1.3 \mathrm{~kg}$, which was almost at the level of the control. In hybrids 'Manoko $\mathrm{F}_{1}$ ', 'Orient Star $\mathrm{F}_{1}$ ', 'Vitimo $\mathrm{F}_{1}$ ', 'Suprin $\mathrm{F}_{1}$ ' the weight of the head was 1.9; 2.0; 2.3 and $2.1 \mathrm{~kg}$ respectively. The smallest weight was noted in hybrid 'Richi $\mathrm{F}_{1}$ ' $-0.95 \mathrm{~kg}$, which was $0.45 \mathrm{~kg}$ less than in the control variant.

To assess the degree of maturity of the variety the beginning of production and the value of the crop is of great importance. According to the results of research, the technical maturity of Chinese cabbage hybrids occurred in the first decade of June. The heads were cut with a knife at a minimum mass of $250-300 \mathrm{~g}$.

On average, during the study period, high commercial yields of heads were obtained in hybrids 'Vili $\mathrm{F}_{1}$ ' (31.7 t/ha) and 'Sprinkin $\mathrm{F}_{1}$ ' $(28.7 \mathrm{t} / \mathrm{ha})$, which were 10.0 and $7.0 \mathrm{t} /$ ha more
Quantitative indicators of the chinese cabbage harvest structure

\begin{tabular}{|c|c|c|c|}
\hline Hybrids & $\begin{array}{c}\text { Head } \\
\text { diameter, cm }\end{array}$ & $\begin{array}{l}\text { Head hight, } \\
\mathrm{cm}\end{array}$ & $\begin{array}{c}\text { Head } \\
\text { mass, kg }\end{array}$ \\
\hline 'Pioner $\mathrm{F}_{1}^{\prime}$ - control & 11.9 & 26.8 & 1.4 \\
\hline 'Vili $\mathrm{F}_{1}^{\prime}{ }^{1}$ & 14.2 & 20.5 & 2.1 \\
\hline 'Manoko $\mathrm{F}_{1}^{\prime}$ & 12.8 & 19.8 & 1.9 \\
\hline 'Orient Star $\mathrm{F}_{1}^{\prime}$ & 13.0 & 20.4 & 2.0 \\
\hline 'Vitimo $\mathrm{F}_{1}^{\prime}$ & 12.7 & 22.1 & 2.3 \\
\hline 'Summer Highland $\mathrm{F}_{1}$ ' & 15.6 & 24.7 & 1.8 \\
\hline 'Sprinkin $\mathrm{F}_{1}^{\prime}$ & 11.8 & 22.8 & 1.3 \\
\hline 'Suprin $\mathrm{F}_{1}^{\prime}{ }^{1}$ & 13.1 & 21.9 & 2.1 \\
\hline${ }^{\prime}$ Richi F ${ }_{1}^{\prime}$ & 12.5 & 17.8 & 0.95 \\
\hline $\mathrm{LSD}_{0.05}$ & 0.3 & 0.5 & 0.4 \\
\hline
\end{tabular}

than in the control (Table 3, Fig. 2). The yields of 'Summer Highland $\mathrm{F}_{1}$ ' (24.9) and 'Suprin $\mathrm{F}_{1}$ ' (24.6 t/ha) hybrids were significantly lower. The low yield of marketable products is due to the lower resistance of plants to higher temperatures in the late spring, which led to the formation of loose and smaller heads. 'Monoko $\mathrm{F}_{1}$ ', and 'Vitimo $\mathrm{F}_{1}$ ' hybrids had almost identical yields, which were +1.2 and $+1.5 \mathrm{t} / \mathrm{ha}$, respectively.

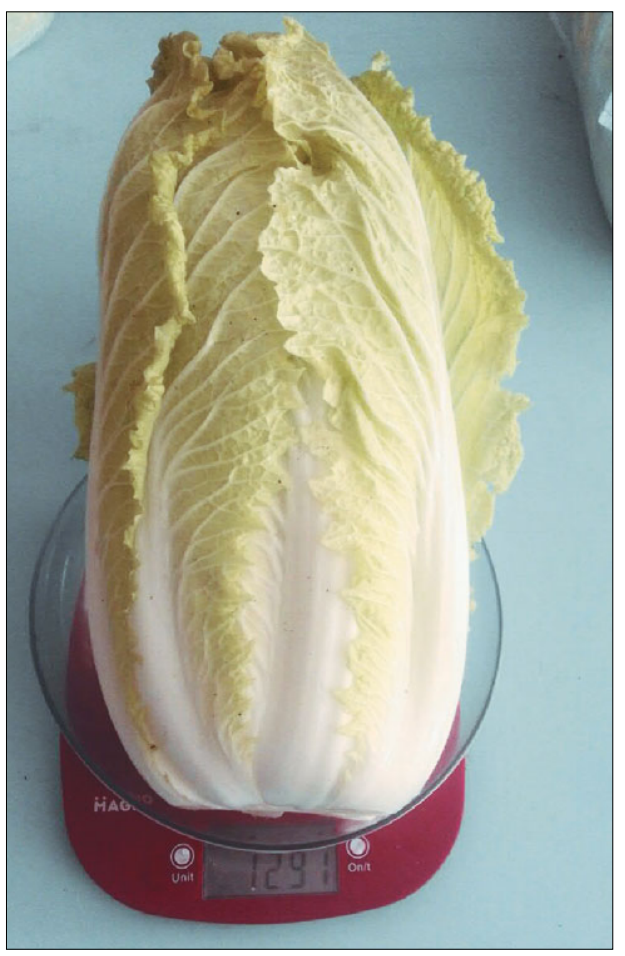

Fig. 2. Cabbage head of hybrid 'Sprinkin $F_{1}$ '

Depending on the weather conditions, the yield of Chinese cabbage hybrids varied separately by year. On average, in the years of research, the greatest increase to control was in hybrids 'Vili $\mathrm{F}_{1}$ ' and 'Sprinkin $\mathrm{F}_{1}$ '. The control variant 'Pioner $F_{1}$ ' had the lowest yield $-21.7 \mathrm{t} / \mathrm{ha}$ on average during the years of research. 
Commodity yield of Chinese cabbage hybrids

\begin{tabular}{|c|c|c|c|c|c|}
\hline \multirow{2}{*}{ Hybrids } & \multicolumn{4}{|c|}{ Commodity yield, $\mathrm{t} / \mathrm{ha}$} & \multirow{2}{*}{$\begin{array}{c} \pm \text { to } \\
\text { control }\end{array}$} \\
\hline & 2017 & 2018 & 2019 & mean & \\
\hline 'Pioner $\mathrm{F}_{1}$ '. & 22.0 & 21.4 & 21.8 & 21.7 & - \\
\hline 'Vili $\mathrm{F}_{1}^{\prime}{ }^{\prime}$ & 35.2 & 29.5 & 30.5 & 31.7 & +10.0 \\
\hline 'Manoko $\mathrm{F}_{1}^{\prime}$ & 23.1 & 22.7 & 23.0 & 22.9 & +1.2 \\
\hline 'Orient Star $\mathrm{F}_{1}^{\prime}$ & 23.5 & 24.3 & 24.6 & 24.1 & +2.4 \\
\hline 'Vitimo $\mathrm{F}_{1}^{\prime}$ & 23.4 & 23.2 & 23.0 & 23.2 & +1.5 \\
\hline 'Summer Highland $\mathrm{F}_{1}$ ' & 25.5 & 24.4 & 24.8 & 24.9 & +3.2 \\
\hline 'Sprinkin $\mathrm{F}_{1}^{\prime}$ & 30.6 & 28.3 & 27.4 & 28.7 & +7.0 \\
\hline 'Suprin $\mathrm{F}_{1}^{\prime}$ & 26.1 & 24.2 & 23.7 & 24.6 & +2.9 \\
\hline 'Richi F' & 21.9 & 21.7 & 22.3 & 20.9 & +0.2 \\
\hline $\mathrm{LSD}_{0.0}$ & 1.4 & 1.7 & 1.2 & 1.5 & - \\
\hline
\end{tabular}

Studies have also shown that Chinese cabbage yields differed not only in biometrics but also in chemical composition. The obtained results indicate that the highest soluble solids content was in the heads of 'Summer Highland $\mathrm{F}_{1}$ ' hybrids $(6.2 \%)$ and 'Sprinkin $\mathrm{F}_{1}$ ' $(5.9 \%)$, what was 1.1 and $0.8 \%$ more than in the control, respectively. There was no significant difference in the amount of sugars over the variants, this indicator was at the level of control (1.7-2.1\%). The content of ascorbic acid was in the range of $38.6-45.0 \mathrm{mg}$, this indicator was in hybrid 'Vili $\mathrm{F}_{1}$ ' $-45.0 \mathrm{mg}$, which is $6.4 \mathrm{mg}$ more than in the control. The content of nitrates in the cabbage heads of the studied Chinese cabbage hybrids was within the tolerance limit and amounted to $600 \mathrm{mg} / \mathrm{kg}$ (fresh mass) and ranged from $350 \mathrm{mg} / \mathrm{kg}$ in 'Summer Highland $\mathrm{F}_{1}$ ' hybrid to $465 \mathrm{mg} / \mathrm{kg}$ wet weight in 'Vili $\mathrm{F}_{1}^{1}$ ' hybrid (Table 4).

Biochemical composition of Chinese cabbage heads

\begin{tabular}{|c|c|c|c|c|}
\hline \multirow{2}{*}{ Hybrids } & \multicolumn{3}{|c|}{ Content in heads } & \multirow{2}{*}{ Sum of sugars, $\%$} \\
\hline & soluble dry matter, $\%$ & ascorbic acid, mg & nitrates, $\mathrm{mg} / \mathrm{kg}$ & \\
\hline 'Pioner $\mathrm{F}_{1}^{\prime}$ - control & 5.1 & 38.6 & 498 & 1.7 \\
\hline 'Vili $\mathrm{F}_{1}^{\prime}{ }^{1}$ & 5.5 & 45.0 & 465 & 2.1 \\
\hline 'Manoko F' & 5.2 & 41.1 & 421 & 1.8 \\
\hline 'Orient Star $\mathrm{F}_{1}{ }^{\prime}$ & 5.2 & 40.8 & 453 & 1.8 \\
\hline 'Vitimo $\mathrm{F}_{1}^{\prime}$ & 5.4 & 41.0 & 445 & 1.7 \\
\hline 'Summer Highland $\mathrm{F}_{1}$ ' & 6.2 & 41.6 & 350 & 2.0 \\
\hline 'Sprinkin F' & 5.9 & 42.1 & 411 & 1.8 \\
\hline 'Suprin $\mathrm{F}_{1}^{\prime}$ & 5.0 & 41.4 & 468 & 1.9 \\
\hline 'Richi F' & 5.2 & 40.7 & 457 & 1.7 \\
\hline
\end{tabular}

Therefore, under the conditions of unstable soil moisture, hybrids 'Villi $\mathrm{F}_{1}$ ' and 'Sprinkin $\mathrm{F}_{1}$ ' appeared the most productive and ensured yield increase of $10.0 \mathrm{t} / \mathrm{ha}$ and $7.0 \mathrm{t} / \mathrm{ha}$, respectively, compared to the control; and the production was of high commercial quality.

\section{Conclusion}

Monitoring the rate of passage of the main phenological phases of Chinese cabbage showed that, having been planted within the same time frame seed germination was not simultaneous. The first sprouted seeds (4 days after seeding) belonged to hybrids 'Vili $\mathrm{F}_{1}$ ', 'Manoko $\mathrm{F}_{1}$ ', 'Orient Star $F_{1}$ ' and 'Summer Highland $F_{1}^{1}$ '. Seeds of the other hybrids started active germination on the 5-6 days after seeding. 'Sprinkin $\mathrm{F}_{1}$ ' hybrid entered the phase of technical ripeness earlier (85 days after germination), which was 5 days faster than in the control. A long vegetation period was observed in the hybrid 'Richi $\mathrm{F}_{1}$ ' - 93 days. The duration of the growing season in other hybrids was at the control level.

The biometric indicators of cabbage showed that in the phase of the beginning of head for- mation plants of 'Sprinkin $\mathrm{F}_{1}$ ' hybrid $(16.5 \mathrm{~cm})$ were the highest, at the control level. This indicator was at the same level in 'Vili $\mathrm{F}_{1}$ ' and 'Summer Highland $\mathrm{F}_{1}$ ' hybrids, respectively 15.7 and $15.5 \mathrm{~cm}$. The lowest plant height was observed in 'Richi $\mathrm{F}_{1}$ ' hybrid $(14.5 \mathrm{~cm})$, due to varietal characteristics of plants.

In the phase of technical maturity, the biggest leafage of plants was observed in hybrids 'Vili $\mathrm{F}_{1}$ ' and 'Sprinkin $\mathrm{F}_{1}$ '; on average over the years of research, the number of leaves was 21.7 and 21.4 pcs./plant, which was 1.6 and 1.3 pcs. more than in control. Plants of hybrid 'Summer Highland $\mathrm{F}_{1}$, in this phase formed the smallest number of leaves 18.3 pcs., what was 1.8 pcs. less than in the control.

The highest commodity crop of heads was obtained for the hybrids 'Vili $\mathrm{F}_{1}$ ' (31.7 t/ha) and Sprinkin F1 (28.7 t/ha), which was 10.0 and $7.0 \mathrm{t} /$ ha more than in the control. The yields of 'Summer Highland $F_{1}$ ' hybrids were significantly lower - 24.9 and the 'Suprin $\mathrm{F}_{1}{ }^{\prime}-$ $24.6 \mathrm{t} / \mathrm{ha}$.

The highest soluble solids content was in the heads of hybrids 'Summer Highland $F_{1}$ ' $(6.2 \%)$ and 'Sprinkin $\mathrm{F}_{1}$ ' $(5.9 \%)$, which was 1.1 and 
$0.8 \%$ more than in the control. By the amount of sugars, there was no significant difference between the options; this indicator was at the control level $(1.7-2.1 \%)$. The nitrate content in the heads of the studied hybrids of Chinese cabbage was within the permissible norm and amounted to $600 \mathrm{mg} / \mathrm{kg}$ of wet weight.

\section{References}

1. Chernetskyi, V. M., \& Shvydkyi, P. A. (2016). Vegetable growing in Ukraine: state, problems, prospects. In Ovochivnytstvo i bashtannytstvo: istorychni aspekty, suchasnyi stan, problemy i perspektyvy rozvytku: materialy IV Mizhnarodnoi naukovo-praktychnoi konferentsii [Vegetables and melons: historical aspects, current status, problems and prospects for development: materials of the IV International Scientific and Practical Conference] (Vol. 2, pp. 168-175). March 12-13, 2018, Kruty, Ukraine. [in Ukrainian]

2. Puzik, L. M., Koltunov, V. A., Romanov, 0. V., Bondarenko, V. A., Haiova, L. 0., \& Shcherbyna, E. (2015). Kapustiani ovochi. Tekhnolohiia vyroshchuvannia i zberihannia [Cabbage vegetables. Growing and storage technology]. Kharkiv: N.p. [in Ukrainian]

3. Reza, M. S., Islam, A. K. M. S., Rahman, M. A., Miah, M. Y., Akhter, S., \& Rahman, M. M. (2016). Impact of organic fertilizers on yield and nutrient uptake of cabbage (Brassica oleracea var. capitata). J. Sci. Technol. Environ. Inform., 3(2), 231-244. doi: $10.18801 /$ jstei.030216.26

4. Park, C. H., Yeo, H. J., Park, S.-Y., Kim, J. K., \& Park, S. U. (2019). Comparative phytochemical analyses and metabolic profiling of different phenotypes of chinese cabbage (Brassica rapa ssp. pekinensis). Foods, 8(11), 587. doi: 10.3390/foods 8110587

5. Khareba, 0. V. (2016). Aspects of scientific support of organic production of low-spread vegetable plants in Ukraine. In Stan ta perspektyvy rozvytku vyrobnytstva orhanichnoi produktsii: materialy Mizhnarodnoi naukovo-praktychnoi konferentsii [Status and Prospects of Organic Production Production: Proceedings of the International Scientific and Practical Conference] (pp. 156-117). July 20,2016, Selektsiine, Kharkiv region, Ukraine. [in Ukrainian]

6. Yarovyi, H. I., \& Nehreba, M. S. (2015). Hybrids crop capacity of pekingese cabbage suitable for growing in the conditions of left bank Forest-Steppe of Ukraine. Visnik HNAU. Seriâ Roslinnictvo, selekciâ i nasinnictvo, plodoovočivnictvo i zberigannâ [The Bulletin of Kharkiv National Agrarian University. Crop Production, Breeding and Seed Production, Horticulture], 2, 126-132. [in Ukrainian]

7. Chuan L., Zheng, H., Sun, S., Wang, A., Liu, J., Zhao, T., \& Zhao, J. A. (2019). Sustainable Way of Fertilizer Recommendation Based on Yield Response and Agronomic Efficiency for Chinese Cabbage. Sustainability, 11(16), 4368. doi: 10.3390/su11164368

8. Wei, Y., Li, F., Zhang, S., Zhang, S., Zhang, H., \& Sun, R. (2018). Characterization of Interspecific Hybrids between Flowering Chinese Cabbage and Chinese Kale. Agronomy, 8(11), 258. doi: 10.3390/agronomy 8110258

9. Jeongyeo, L., Young-Hee, N., Kun-Hyang, P., Dae-Soo, K., Han, T. J., Haeng-Soon, L., Sung, R., \& HyeRan, K. (2016). Environmentally friendly fertilizers can enhance yield and bioactive compounds in Chinese cabbage (Brassica rapa ssp. pekinensis). Turk. J. Agr. For., 43(2), 138-150. doi: 10.3906/tar-1807-28

10. Xiang, Y. Y., Huang, Y. X., Huang, C. Y., Liu, L. S., Long, Q., \& Long, H. Yu. (2018). Influence of different water supply negative pressure on growth and main physiological indexes of Chinese cabbage. J. Agric. Sci. Technol. (Beijing), 20(8),16-22. doi: 10.13304/j.nykjdb.2017.0779

11. Su, T., Li, P., Wang, H., Wang, W., Zhao, X., Yangjun, Y., Shuancang, Y., \& Fenglan, Z. (2019). Natural variation in a calreticulin gene causes reduced resistance to $\mathrm{Ca}^{2+}$ deficiencyinduced tipburn in Chinese cabbage (Brassica rapa ssp. pekinensis). Plant Cell Environ., 42(11), 3044-3060. doi: 10.1111/ pce.13612
12. Yarovyi, H. I., \& Nehreba, M. S. (2016). Influence of feeding area on yield of Beijing Suprin $F_{1}$ cabbage in conditions of Left Bank Forest Steppe of Ukraine. Visnik HNAU. Seriâ Roslinnictvo, selekciâ i nasinnictvo, plodoovo čivnictvo i zberigannâ [The Bulletin of Kharkiv National Agrarian University. Crop Production, Breeding and Seed Production, Horticulture], 1, 152-158. [in Ukrainian]

13. Bondarenko, H. L., \& Yakovenko, K. I. (Eds.). (2001). Metodyka doslidnoi spravy $v$ ovochivnytstvi $i$ bashtannytstvi [Methods of conducting experiments in vegetable and melon growing]. ( $3^{\text {rd }}$ ed., rev.). Kharkiv: Osnova. [in Ukrainian]

14. Hrytsaienko, Z. M., Hrytsaienko, A. 0., \& Karpenko, V. P. (2003). Metody biolohichnykh ta ahrokhimichnykh doslidzhen roslyn $i$ gruntiv [Methods of biological and agrochemical research of plants and soil]. Z. M. Hrytsaienko (Ed.). Kyiv: Nichlava. [in Ukrainian]

15. Ermantraut, E. R., Prysiazhniuk, 0. I., \& Shevchenko, I. L. (2007). Statystychnyi analiz ahronomichnykh doslidnykh danykh $v$ paketi Statistica 6.0 [Statistical analysis of agronomic study data using the Statistica 6.0 software suite]. Kyiv: PolihrafKonsaltynh. [in Ukrainian]

\section{Використана література}

1. Чернецький В. М., Швидкий П. А. Овочівництво України: стан, проблеми, перспективи розвитку. Овочівництво і баштанництво: історичні аспекти, сучасний стан, проблеми і перспективи розвитку : матер. IV Міжнар. наук.-практ. конф. (с. Крути, 12-13 березня 2018 р.). Обухів, 2018. Т. 2. C. $168-175$.

2. Пузік Л. М., Колтунов В. А., Романов О. В. та ін. Капустяні овочі. Технологія вирощування і зберігання. Харків, 2015. 374 С.

3. Reza M. S., Islam A. K. M. S., Rahman M. A. et al. Impact of organic fertilizers on yield and nutrient uptake of cabbage (Brassica oleracea var. capitata). J. Sci. Technol. Environ. Inform. 2016. Vol. 3, Iss. 2. P. 231-244. doi: 10.18801/jstei.030216.26

4. Park C. H., Yeo H. J., Park S.-Y. et al. Comparative phytochemical analyses and metabolic profiling of different phenotypes of chinese cabbage (Brassica rapa ssp. pekinensis). Foods. 2019. Vol. 8, Iss. 11. 587. doi: 10.3390/foods 8110587

5. Хареба 0. В. Аспекти наукового забезпечення органічного виробництва малопоширених овочевих рослин в Україні. Стан та перспективи розвитку виробництва органічної продукції : матер. Міжнар. наук.-практ. конф. (сел. Селекційне, Харківська обл., 20 липня 2016 р.). Харків, 2016. C. 117-124.

6. Яровий Г. І., Негреба М. С. Урожайність гібридів капусти пекінської, придатних до вирощування в умовах Лівобережного Лісостепу України. Вісник ХНАУ. Сер. : Рослинництво, селекція $і$ насінництво, плодоовочівництво. 2015. Вип. 2. C. 126-132.

7. Chuan L., Zheng H., Sun S. et al. Sustainable Way of Fertilizer Recommendation Based on Yield Response and Agronomic Efficiency for Chinese Cabbage. Sustainability. 2019. Vol. 11, Iss. 16. 4368. doi: 10.3390/su11164368

8. Wei Y., Li F., Zhang S. et al. Characterization of Interspecific Hybrids between Flowering Chinese Cabbage and Chinese Kale. Agronomy. 2018. Vol. 8, Iss. 11. 258. doi: 10.3390/ agronomy 8110258

9. Jeongyeo L., Young-Hee N., Kun-Hyang P. et al. Environmentally friendly fertilizers can enhance yield and bioactive compounds in Chinese cabbage (Brassica rapa ssp. pekinensis). Turk. J. Agr. For. 2019. Vol. 43, Iss. 2. P. 138-150. doi: 10.3906/tar-1807-28

10. Xiang Y. Y., Huang Y. X., Huang C. Y. et al. Influence of different water supply negative pressure on growth and main physiological indexes of Chinese cabbage. J. Agric. Sci. Technol. (Beijing). 2018. Vol. 20, Iss. 8. P. 16-22. doi: 10.13304/ j.nykjdb.2017.0779

11. Su T., Li P., Wang H. et al. Natural variation in a calreticulin gene causes reduced resistance to $\mathrm{Ca}^{2+}$ deficiency-induced tipburn 
in Chinese cabbage (Brassica rapa ssp. pekinensis). Plant Cell Environ. 2019. Vol. 42, Iss. 11. P. 3044-3060. doi: 10.1111/ pce. 13612

12. Яровий Г. І., Негреба М. С. Вплив площі живлення на урожайність капусти пекінської Супрін $\mathrm{F}_{1}$ в умовах Лівобережного Лісостепу України. Вісник ХНАУ. Сер. : Рослинництво, селекція і насінництво, плодоовочівництво. 2016. Вип. 1. С. 152-158.
13. Методика дослідної справи в овочівництві і баштанництві / за ред. Г. Л. Бондаренка, К. І. Яковенка. 3-тє вид., пер. і доп. Харків : Основа, 2001. 369 с.

14. Грицаєнко 3. М., Грицаєнко А. 0., Карпенко В. П. Методи біологічних та агрохімічних досліджень рослин і ґрунтів / за ред. 3. М. Грицаєнко. Київ : Нічлава, 2003. 320 с.

15. Ермантраут Е. Р., Присяжнюк 0. І., Шевченко І. Л. Статистичний аналіз агрономічних дослідних даних в пакеті Statistica 6.0. Київ : ПоліграфКонсалтинг, 2007. 56 с.

\section{УДК 631.544.7:582.683.211.6}

Ковтунюк 3. I. ${ }^{1}$, Войтовська В. I. ${ }^{2}$, Сторожик Л. I. ${ }^{2}$ Господарсько-біологічна оцінка гібридів капусти пекінської [Brassica rapa L. var. pekinensis (Lour.) Kitam.] за вирощування в умовах Правобережного Лісостепу України // Plant Varieties Studying and Protection. 2020.T. 16, № 1. С. 40-47. https://doi.org/10.21498/25181017.16.1.2020.201026

${ }^{1}$ Уманський національний університет садівництва, вул. Інститутська, 1, м. Умань, Черкаська обл., 20305, Україна, e-mail: kovpetfom@ukr.net

${ }^{2}$ Iнститут біоенергетичних культур і иукрових буряків НААН України, вул. Клінічна, 25, м. Київ, 03110, Україна

Мета. Дослідити господарсько-біологічні особливості та розкрити генетичний потенціал різних гібридів капусти пекінської залежно від кліматичної зони вирощування. Методи. Варіантами досліду були гібриди капусти пекінської 'Pioner $\mathrm{F}_{1}^{\prime}$ (контроль), 'Vili $\mathrm{F}_{1}^{\prime}$, 'Manoko $\mathrm{F}_{1}$ ', 'Orient Star $\mathrm{F}_{1}{ }^{\prime}$, Vitimo $\mathrm{F}_{1}{ }^{\prime}$, Sprinkin $\mathrm{F}_{1}{ }^{\prime}$ 'Summer Highland $\mathrm{F}_{1}{ }^{\prime}$,'Suprin $\mathrm{F}_{1}{ }^{\prime}$, 'Richi $F_{1}^{\prime}$. Площа облікової ділянки $21 \mathrm{~m}^{2}$. Дослід закладався в чотирьох повтореннях, досліджувані варіанти розміщували методом рендомізованих блоків. Касетну розсаду віком 40 діб висаджували в другій декаді квітня за схемою $70 \times 25$ см. Результати. За одного строку сівби у гібридів сходи з'являлись неодночасно і перші відмічено у гібридів 'Vili $F_{1}$ ', 'Manoko $F_{1}$ ', 'Orient Star $F_{1}^{\prime}$ та 'Summer Highland $\mathrm{F}_{1}^{\prime}$ - на 4 добу після сівби, а у решти - масові сходи спостерігали дещо пізніше, на 5-6 добупісля сівби. Найвищий товарний врожай головок одержали у гібридів 'Vili F' ' $^{2} 1,7$ т/ га) та 'Sprinkin $F_{1}^{\prime}(28,7 \mathrm{~T} /$ га), що на 10,0 і 7,0 т/га більше, ніж у контролі. Істотно нижчою була врожайність у гібридів 'Summer Highland F' - 24,9 i 'Suprin $F_{1}^{\prime}$ - 24,6 т/га. В умовах нестійкого зволоження врожайнішими були гібриди 'Vili F' ${ }_{1}^{\prime}$ та 'Sprinkin $\mathrm{F}_{1}$ ', які забезпечили приріст урожаю до контролю
10,0 і 7,0 т/га, а продукція була високої товарної якості. Найвищий відсоток сухих розчинних речовин був у головках гібридів 'Summer Highland $F_{1}^{\prime}(6,2 \%)$ i 'Sprinkin $F_{1}^{\prime}(5,9 \%)$, що на 1,1 і 0,8\% більше за контроль. За сумою цукрів не відмічено істотної різниці між варіантами, даний показник був на рівні контролю $(1,7-2,1 \%)$. Уміст нітратів у головках досліджуваних гібридів капусти пекінської був у межах допустимої норми - 600 мг/кг сирої маси. Висновки. Фенологічні спостереження за розвитком рослин та їхні біометричні показники залежно від сортових особливостей вказують, що в умовах нестійкого зволоження врожайнішими були гібриди 'Vili $\mathrm{F}_{1}$ 'та 'Sprinkin $\mathrm{F}_{1,}^{\prime}$ які забезпечили приріст урожаю до контролю 10,0 i 7,0 т/га, а продукція була високої товарної якості. Тривалий період вегетації у гібриду 'Richi $\mathrm{F}_{1}$ ' 93 доби, не вплинув на якість і врожайність та забезпечив найнижчі показники відносно контрольного i досліджуваних варіантів.

Ключові слова: головка; біометричні показники; фенологічні спостереження; вміст нітратів; урожайність.

\section{УДК 631.544.7:582.683.211.6}

Ковтунюк 3. И. ${ }^{1}$, Войтовская В. И. ${ }^{2}$, Сторожик Л. И. ${ }^{2}$ Хозяйственно-биологическая оценка гибридов капусты пекинской [Brassica rapa L. var. pekinensis (Lour.) Kitam.], выращенных в условиях Правобережной Лесостепи Украины // Plant Varieties Studying and Protection. 2020. T. 16, № 1. С. 40-47. https://doi.org/10.21498/2518-1017.16.1.2020.201026

ууманский национальный университет садоводства, ул. Институтская, 1, г. Умань, Черкасская обл., 20305, Украина, e-mail:kovpetfom@ukr.net

${ }^{2}$ Институт биоэнергетических культур и сахарной свеклы НААН Украины, ул. Клиническая, 25, г. Киев, 03110, Украина

Цель. Исследовать хозяйственно-биологические особенности и раскрыть генетический потенциал различных гибридов капусты пекинской в зависимости от климатической зоны выращивания. Методы. Вариантами опыта были гибриды капусты пекинской 'Pioner F' (контроль), 'Vili $F_{1}^{\prime}$ ', 'Manoko $F_{1}^{\prime}$ ', 'Orient Star $F_{1}^{\prime}$, 'Vitimo $F_{1}^{\prime}$ ', Sprinkin $F_{1}^{\prime}$ ', 'Summer Highland $F_{1}^{\prime}$ ' 'Suprin $F_{1}$,' 'Richi $F_{1}$.' Площадь учетного участка $21 \mathrm{~m}^{2}$. Опыт закладывался в четырех повторениях, исследуемые варианты размещали методом рендомизированных блоков. Кассетную рассаду в возрасте 40 суток высаживали во второй декаде апреля по схеме $70 \times 25$ см. Результаты. В один срок посева у гибридов всходы появлялись не одновременно и первые отмечены у гибридов 'Vili $F_{1}^{\prime}$, 'Manoko $F_{1}^{\prime}$,' 'Orient Star $F_{1}^{\prime}$ и 'Summer Highland $\mathrm{F}_{1}^{\prime}$ - на 4 сутки после посева, а в остальных массовые всходы наблюдались несколько позже, на 5-6 сутки после посева. Самый высокий товарный урожай головок получили у гибридов 'Vili F' ' $\left._{1} 31,7 \mathrm{~T} / \mathrm{ra}\right)$ и 'Sprinkin F ${ }_{1}^{\prime}$ $(28,7$ т/га), что на 10,0 и 7,0 т/га больше, чем в контроле. Существенно ниже была урожайность у гибридов 'Summer Highland $\mathrm{F}_{1}^{\prime}-24,9$ и 'Suprin $\mathrm{F}_{1}^{\prime}-24,6$ т/га. В условиях неустойчивого увлажнения более урожайными были гибриды 'Vili $F_{1}^{\prime}$ и 'Sprinkin F', которые обеспечили прирост урожая к контролю 10,0 и 7,0 т/га, а продукция имела высокое товарное качество. Самый высокий процент сухих растворимых веществ установлен в головках гибридов 
'Summer Highland $\mathrm{F}_{1}^{\prime}(6,2 \%)$ и 'Sprinkin $\mathrm{F}_{1}^{\prime}$ (5,9\%), что на 1,1 и 0,8\% больше контроля. По сумме сахаров не отмечено существенной разницы между вариантами, данный показатель был на уровне контроля (1,7-2,1\%). Содержание нитратов в головках исследуемых гибридов капусты пекинской было в пределах допустимой нормы 600 мг/кг сырой массы. Выводы. Фенологические наблюдения за развитием растений и их биометрические показатели в зависимости от сортовых особенностей указывают, что в условиях неустойчивого увлажнения более урожайными были гибриды 'Vili $F_{1}^{\prime}$ и 'Sprinkin $F_{1}^{\prime}$, которые обеспечили прирост урожая к контролю 10,0 и 7,0 т/га, а продукция была высокого товарного качества. Длительный период вегетации у гибрида 'Richi $F_{1}^{\prime}$ - 93 суток не повлиял на качество и урожайность культуры и обеспечил низкие показатели относительно контрольного и исследуемых вариантов.

Ключевые слова: качан; биометрические показатели; фенологические наблюдения; содержание нитратов; урожайность. 